\title{
Prospecting the Future - Shaping Prospectus Provisions for the Benefit of SMEs*
}

\author{
BY ANDRÁs KeCSKÉS**
}

\begin{abstract}
The European Commission has started the review of the prospectus regulation scheme in 2013 in order to facilitate the development of the Capital Markets Union. One of the aims of the reforms intends to give access to small -medium sized enterprises (SMEs) to the capital markets throughout Europe. The reason behind that is to make those companies less dependent on loans and other debt-based capital raising methods to unlock their full potential. Studies have shown that the European SME sector is heavily dependent on banks for financing, which actually hurts their prospects in the long run. Gaining access to the public capital markets can be mainly achieved by getting listed. Unfortunately, there are many regulatory hurdles which a company must face in order to successfully launch themselves on stock exchanges. One of such is the preparation of the so-called prospectus document. The aim of the paper is to explore the mandatory content requirements for prospectuses in Europe for SMEs and through that to find out if the current provisions are adequate.
\end{abstract}

Keywords: IPO, due diligence, prospectus, SME, Capital Markets Union

\section{INTRODUCTION}

Facilitating the growth and prosperity of SMEs has always been in the forefront of EU policies. The importance of SMEs is underlined by the fact that they provide the large majority of jobs in European Union. ${ }^{1}$ Unfortunately, their competitiveness leaves a lot to be desired, especially afterwards the financial crises of 2008. Their disadvantage stems from many factors, one of them being hardships of accessing capital. Normally, an enterprise wishing to raise funds may resort to two methods. The classical way would be obtaining a loan from a bank. Debt-based capital has many disadvantages, though, one of which is finding guarantors for its debts. Also, we must not forget about that a bank is only interested in receiving the returns from its investments. If any problem arises threatening the return of investment, then it has no qualms about starting procedures recouping the sums invested potentially endangering the company's long term operations. Also, if further capital is needed, the cost of obtaining a loan increases. According to studies conducted by the European Commission, enterprises in Europe rely mostly on debts to raise capital. However, the costs of loans increased due to the financial crises, thus many SMEs have become ineligible for a loan, stunting their potential growth. That is why the European Commission was interested in encouraging SMEs to list themselves so that banks as intermediaries can be omitted.

The benefits of going public are numerous. Such benefits include but are not limited to a) the increase in share capital, b) easy access to alternative sources of capital, c) increased reliability and prestige of the company, d) increases liquidity of the company, e) increased

* This paper has been supported by the János Bolyai Research Scholarship of the Hungarian Academy of Sciences.

** Associate professor at the University of Pécs. E-mail: kecskes.andras@ajk.pte.hu

1 Variale Gemma, 'Fixing Europe's Funding Model' [2013] 32(6) International Financial Law Review 31. 
motivation for management and employees alike f) enhanced transparency. ${ }^{2}$ It has to be stated that not all SMEs can benefit from going public. The only kind of enterprises which can potentially reap the benefits of going public are the so-called "high-growth SMEs". Another benefit of an initial public offering (IPO) for SMEs in European context would be the cross-border access to capital. Also, contrary to debt based capital, equity based capital can be obtained much cheaper. It has to be emphasised, that the costs incurred upfront are much higher than of the costs of a bank loan, initially. But in the long run, it can be safely said that equities are much more beneficial for the companies.

Going public is not an easy task, though. The road towards the world of stock exchanges is a long and winding one; there are many stages before a successful IPO could be made. The first, and foremost is to issue a so-called prospectus document. The disclosure rules and the due diligence procedures can be rather costly, which might discourage some enterprises. They have to bear the costs of complying with the regulations regarding IPOs, underwriters and the costs arising from underpricing. ${ }^{3}$ The aim of this paper is to find out whether the current and the proposed prospectus regulations are beneficial for SMEs to become listed on stock exchanges. The relevance of the topic is underlined by the fact that the European Commission recently conducted a consultation about the review of the Prospectus Directive. The aim of the consultation was to facilitate reforms which will lead to increased competitiveness of the Capital Markets Union and through that to unlock the potential in SMEs.

The paper is divided into six main sections. Firstly, an overview is intended to be given on the situation of SMEs in Europe. With that the intention is to familiarise the readers with the problems SMEs are currently facing and how equity capital may solve their problems. The second section wishes to show some basic concepts regarding prospectuses and to highlight their role in the course of an IPO. The third section aims at describing the provisions regarding the prospectus document on a European level. It must be noted beforehand that a special emphasis will be placed on Regulation 809/2004/EC due to the fact that it contains the mandatory content requirement for prospectuses. Getting acquainted with the current regulatory scheme is important, for the analysis requires an indepth knowledge of the relevant law. The fourth section intends to overview some problems regarding the current provisions by using the results of the survey conducted by the European Commission between $18^{\text {th }}$ February 2015 and $13^{\text {rd }}$ May 2015. The intention is to show that the current content requirements are cumbersome for SMEs and potential investors alike. The fifth section wishes to explore the possible future regarding public equity capitalisation for SMEs in a European context. The sixth and last part is aimed at summarising of some of the findings of this paper.

2 András Kecskés and Vendel Halász, Stock Corporations - A Guide to Initial Public Offerings, Corporate Governance, and Hostile Takeover (Anna Tolnai and others trs, HVG-ORAC-LexisNexis 2013). From this it can also be concluded that IPOs can promote good corporate governance. The lack of transparency may have disastrous results, which in turn may cost lives. For an egregious case arising from the aforementioned see: Barnabás Ferencz, 'Felelős társaságirányítási felvetések a General Motors gyújtáskapcsoló-botrány tükrében’ [2015] 21(2) JURA 170-174.

${ }^{3}$ Stéphane Rousseau, 'The Future of Capital Formation for Small and Medium-sized Enterprises: Rethinking Initial Public Offering Regulation after the Restructuring of Canadian Stock Exchanges' [2000] 34(3) Revue Juridique Themis 669. 


\section{THE SME SITUATION IN EUROPE}

The importance of SMEs cannot be understated. As it was pointed out in the introduction, they are major source of jobs and a driving force of local economies. They contribute to the $2 / 3$ rds of private sector jobs and more than half of the total value added created by business activity. ${ }^{4}$ Yet they cannot unlock their full potential. The European Commission in their Action Plan for building a Capital Markets Union \{COM(2015) 468 final $\}$ tried to identify the obstacles which hinder their progress. But before reviewing the findings of the Commission, it is worthwhile to identify the main characteristics of SMEs.

The definition of SME can be found in Commission Recommendation of 6 May 2003. A business entity must meet two of the following criteria to qualify as an SME: a) the balance sheet total must not exceed 43 million EUR, b) the net turnover cannot be over 50 million EUR, c) the average number of employees is no more than 250 . The recommendation makes distinction between medium-sized, small and micro enterprises as well.

For the purposes of our article, the needs of the "high-growth" SMEs will be assessed. Those are the ones after all, which require the most capital for pursuing their economic activities. According to Michael J. Whincop, ${ }^{5}$ they are characterised by having a separate management and ownership and significant reliance on "outside equity." $\mathrm{A}$ good example for such businesses would be the ones in the IT sector.

According to the economic analysis accompanying the Capital Markets Union Action plan $^{7}$, most of the SMEs were heavily reliant on debt based equities. One reason for that is the economic convention in Europe, where banks were traditionally the ones financing the capital needs for business entities. Being dependent on one source of capital makes these businesses vulnerable, though, especially in less-developed member states, such as Greece. ${ }^{8}$ The 2013 Survey on the Access to Finance of Enterprises (SAFE) shows that 35\% of SMEs were unable to obtain the financing they asked for. ${ }^{9}$ The rate of unsuccessful loan applications varied widely on a member state-basis. For example, 68\% of the SMEs in The Netherlands were denied on their financing application in contrast with the 13\% of SMEs in Germany. ${ }^{10}$ Another major problem relating to debt based capitalisation for SMEs is that even if they get the financing they asked for, they are provided at less attractive terms than larger companies. ${ }^{11}$ This is especially problematic, considering how SMEs are undercapitalised most of the time.

Thus the Commission believes that fostering equity-based capital for SMEs via the Capital Markets Union would be the solution for the problems listed. A cross-border

${ }^{4}$ Commission, 'Action Plan on Building a Capital Markets Union' (Economic Analysis) COM (2015) 468 final.

${ }^{5}$ Michael J Whincop (1968-2003) was a professor at the Law Faculty of Griffith University.

${ }^{6}$ Michael J Whincop, 'Due Diligence in SME Fundraising: Reform Choices, Economics and Empiricism' [1996] 19(2) UNSW Law Journal.

${ }^{7} \mathrm{COM}(2015) 468$ final.

${ }^{8} \mathrm{COM}(2015) 468$ final.

92013 Smes'Access To Finance Survey (1st edn, European Commission 2013) 70.

$<$ http://ec.europa.eu/DocsRoom/documents/7864/attachments/1/translations/en/renditions/native $>$ accessed 14 January 2016.

102013 Smes'Access To Finance Survey (1st edn, European Commission 2013) 35.

$<$ http://ec.europa.eu/DocsRoom/documents/7864/attachments/1/translations/en/renditions/native> accessed 14 January 2016.

${ }_{11}$ COM (2015) 468 final. 
allocation of capital could overcome the differences between member states, thus greatly reducing the costs of accessing capital. In order to do so, the flow of capital needs to be facilitated in the CMU.

\section{THE PURPOSE AND MAIN FEATURES OF PROSPECTUS DOCUMENTS IN IPO TRANSACTIONS}

In the course of an initial public offering the prospectus is the primary informational and marketing document for investors. In fact, the issuer tells the story of the company (and that of the security) in this document. ${ }^{12}$ It contains all the information that might be necessary for the investors for making a decision regarding the investment. ${ }^{13}$ During its preparation it also has to be taken into consideration that the prospectus must comply with the rules of the stock exchange where the securities are to be listed. For issuing shares at foreign markets it is advisable to prepare the prospectus in the language used in the international financial sector.

In principle, each state, securities commission and stock exchange has its own regulation concerning the content of the prospectus. In practice, the differing regulation authorities" mandate for the prospectus are quite similar. In 1998 the International Organization of Securities Commissions (IOSCO) released its own international disclosure standards (International Disclosure Standards) in order to promote cross-border offerings. The standards are meant to guarantee the comparability of information and high levels of investor protection. As content requirements of the prospectus, ten different categories are indicated. The order and organization of information can be changed, but each item has to be incorporated. This is important, because the effective Community regulation on prospectus is also founded on the above standards with regard to the content requirements. ${ }^{14}$ In the European Union, Commission Regulation (EC) No 809/2004 lays down the format of prospectus and the minimum information requirements to be included in a prospectus. ${ }^{15}$

The prospectus is indispensable during the transaction for three reasons. Firstly, it is a statutory obligation to prepare one, secondly, it is an essential marketing tool, and thirdly, an accurate prospectus reduces possible liability arising from misleading investors. Thus, it has to fulfil several functions. As it reduces the liability of the company's management, it should be sufficiently long, yet to-the-point. Nevertheless, its marketing function should not be neglected during the preparation. ${ }^{16}$

The disclosure of the prospectus provides the investors the necessary data in order to evaluate the securities. ${ }^{17}$ It gives an accurate picture of the shares offered for purchase, the

12 See Ross Geddes, IPOs and Equity Offerings (Butterworth-Heinemann 2008) 95.

${ }^{13}$ See Ross Geddes, IPOs and Equity Offerings (Butterworth-Heinemann 2008) 54.

${ }^{14}$ See Ross Geddes, IPOs and Equity Offerings (Butterworth-Heinemann 2008) 95-97.

15 See András Kecskés and Vendel Halász, Stock Corporations - A Guide to Initial Public Offerings, Corporate Governance, and Hostile Takeover (Anna Tolnai and others trs, HVG-ORACLexisNexis 2013) 69-71.

16 See Ross Geddes, IPOs and Equity Offerings (Butterworth-Heinemann 2008) 95-97; András Kecskés and Vendel Halász, Stock Corporations - A Guide to Initial Public Offerings, Corporate Governance, and Hostile Takeovers (Anna Tolnai and others trs, HVG-ORAC-LexisNexis 2013) 6971.

17 See James C Spindler, 'IPO Liability and Entrepreneurial Response' (2007) U Pa L Rev Vol $1551187,1195-1201$. 
financial situation of the company and its capital structure. It contains the description of the company's business activity, and the presentation of business results from the last period. ${ }^{18}$ The composition of these data is primarily the task of the issuer and the investment service provider acting as lead bank. The basis of the prospectus is the information reviewed and compiled in the course of the due diligence investigation. Consultants of investment service providers participating in the transaction also review and complete the prospectus ${ }^{19}$, and auditors check all of its statements of financial relevance, and confirm their accuracy (this is called the comfort letter). Regarding questions of liability, the legal advisor assists in the preparation of the document. However, it is the company which is liable for the content and the accuracy of the data. ${ }^{20}$

The legal advisor also reports on whether the prospectus can be regarded as complete, and whether the data included in it are accurate.

The prospectus has a significant marketing role as well, as it is advisable to make a favourable impact and to promote purchase intentions. Therefore, it contains the strategy of the company and its investment activity; it also indicates the position of the company within the industry. Preparing the prospectus is an important and time-consuming element of the IPO process. Full length of a prospectus might be between 300 to 400 pages and sufficient time, typically one or two months, depending on the company and data to be processed, must be allocated for its preparation in the transaction timetable. The issuer, legal advisor, the auditors and investment service providers also take part in preparing the prospectus and drafting requires considerable experience in order to find the delicate balance of the different functions. ${ }^{21}$ It is especially important in light of the fact that conflicts of interests may arise between issuer and the underwriter during an IPO. As stated by Zsolt Bujtár, this was the main reason behind the ruling of NASDAQ to use independent investment bank as an adviser. ${ }^{22}$

Prospectuses are an invaluable tool for resolving the information asymmetry between the potential investor and the issuer. The core problem is that investors do not have full knowledge about the investment they are about to make which makes them wary. George A. Akerlof ${ }^{23}$ observed this phenomenon as well. He explained that if there is not enough information available on the market, then distortions can occur. He likened this phenomenon to the used car market, where it manifests in either the bad products driving out the good

18 See Ross Geddes, IPOs and Equity Offerings (Butterworth-Heinemann 2008) 95.

19 See Michael Coke, 'Success in the Form of an IPO: A Brief Case Study of A123 Systems, Inc.' (2009) Nanotech L \& Bus Vol 6 513, 519.

20 See András Kecskés and Vendel Halász, Stock Corporations - A Guide to Initial Public Offerings, Corporate Governance, and Hostile Takeovers (Anna Tolnai and others trs, HVG-ORACLexisNexis 2013) 69-71.

21 See András Kecskés and Vendel Halász, Stock Corporations - A Guide to Initial Public Offerings, Corporate Governance, and Hostile Takeovers (Anna Tolnai and others trs, HVG-ORACLexisNexis 2013) 69-71.

22 See Zsolt Bujtár, 'Gondolatok Kecskés András és Halász Vendel "Stock Corporations a Guide to Initial Public Offerings, Corporate Governance and Hostile Takeovers" címü könyvéről' [2015] 15(11) Európai jog 34.

23 George A. Akerlof is an economist and the author of the paper called "The Market for Lemons: Quality Uncertainty and the Market Mechanism" for which he was awarded a Nobel Memorial Award. 
products or in suboptimal pricing. ${ }^{24}$ In the case of securities, it means that less is offered than what their potential value. This in turn manifests as unrealised gains on the issuers side, making IPOs costlier due to the loss. However, a well-prepared prospectus boosts investor confidence, resulting in more appropriate initial prices.

The necessity of prospectus documents has always been argued. As far as back in the 1970's it was argued that such documents were of little value to investors, due to the fact that they were mostly restatements of past events and contained little to no predictions of the future. The prohibition of predictions and other "soft elements" were stemming from the practice of the Securities Exchange Commission, which firmly believed in the possibility of predicting the future from past events. ${ }^{25}$ Another critique pertaining to prospectus documents and disclosure requirement was made by Homer Kripke. ${ }^{26}$ In his paper the "Myth of the Informed Layman" he stated that prospectus documents were "routine, meaningless documents" not fulfilling their purpose, and the registration process "was simply a useless but lucrative bit of paper work." He also criticised prospectus documents on the ground of being nothing else than a disclaimer in case anything went wrong. ${ }^{27}$ According to his findings, most of the prospectus documents painted a gloomy picture of the issuer, which he made a parody of with the following sentence: "Our competition is too much for us, and no representation is made that we will stay out of bankruptcy after the closing date." 28 But the constant "wolf crying" in prospectus documents would shy away investors from making an investment. That is why sophisticated investors and institutional investors were more likely to use the due diligence reports instead of the prospectuses filed at SEC. ${ }^{29}$ Another criticism regarding prospectus documents stems from their preparation cost, which stem from such factors as the aforementioned due diligence procedures and the expenses of regulatory compliance. The Swedish government estimates that producing a prospectus for an IPO approximately costs between $108000-753000 \mathrm{EUR}^{30}$

\section{THE EU REGULATORY SCHEME FOR PROSPECTUS DOCUMENTS}

The preparation of the prospectus is regulated in the European Union by 'Directive 2003/71/ EC on the prospectus to be published when securities are offered to the public or admitted to trading and amending Directive 2001/34/EC' (Prospectus Directive). However, 'Commission Regulation (EC) No 809/2004 of 29 April 2004 implementing Directive

${ }^{24}$ See George A Akerlof, "The Market for "Lemons": Quality Uncertainty and the Market Mechanism' [1970] 84(3) The Quarterly Journal of Economics 489-490 and 499.

${ }^{25}$ See Bruce Alan Mann, 'Prospectuses: Unreadable or Just Unread? - A Proposal to Reexamine Policies Against Permitting Projections' [1971] 40(2) The George Washington Law Review.

${ }^{26}$ Homer Kripke (1912-1995) professor emeritus of law both at New York University and the University of San Diego. He took part in the development of the Uniform Commercial Code, and also he advanced the field of modern consumer credit, commercial financing and accounting.

27 See Homer Kripke, 'The Myth of the Informed Layman' [1973] 28(2) The Business Lawyer.

${ }^{28}$ See Homer Kripke, 'The Myth of the Informed Layman' [1973] 28(2) The Business Lawyer 635.

${ }^{29}$ See Homer Kripke, 'The Myth of the Informed Layman' [1973] 28(2) The Business Lawyer 635 and Homer Kripke, 'A Search for a Meaningful Securities Disclosure Policy' [1975] 31(2) The Business Lawyer 293.

${ }^{30}$ See Ministry of Finance, Finansinspektionen and Sveriges Riksbank, "The Swedish Government And The Swedish Authorities' Common Answer To The Consultation On A Review Of The Prospectus Directive" (2015) 3. 
2003/71/EC of the European Parliament and of the Council as regards information contained in prospectuses as well as the format, incorporation by reference and publication of such prospectuses and dissemination of advertisements' contains the exact, detailed and obligatory rules of the content of the prospectus in the European Union.

Out of the aforementioned, the provisions of the Regulation will be analysed. Through that the intention is to demonstrate the hurdles SMEs have to overcome during the due diligence process.

\section{PROVISIONS OF REGULATION 809/2004/EC ON THE CONTENTS OF THE PROSPECTUS}

Pursuant to the Prospectus Directive, Article 25 of the Regulation sets forth that it is possible for an issuer, an offeror or a person asking for the admission to trading on a regulated market to draw up the prospectus as a single document. In this case, it contains the following parts in the following order: clear and detailed table of contents, the summary - provided for in Article 5 (2) of Directive 2003/71/EC -, the risk factors linked to the issuer and the type of security covered by the issue, the other information items included in the schedules and building blocks according to which the prospectus is drawn up. ${ }^{31}$

Building block means a list of additional information requirements, not included in one of the schedules, to be added to one or more schedules, as the case may be, depending on the type of instrument and/or transaction for which a prospectus or base prospectus is drawn up. ${ }^{32}$

If an issuer, an offeror or a person asking for the admission to trading on a regulated market chooses - according to Article 5 (3) of Directive 2003/71/EC - to draw up a prospectus composed of separate documents, the securities note and the registration document shall be each composed of the following parts in the following order: a clear and detailed table of contents; as the case may be, the risk factors linked to the issuer and the type of security covered by the issue; the other information items included in the schedules and building blocks according to which the prospectus is drawn up. The order of these parts cannot be altered. ${ }^{33}$

However, the issuer, the offeror or the person asking for admission to trading on a regulated market shall be free in defining the order in the presentation of the required information items included in the schedules and building blocks according to which the prospectus is drawn up. ${ }^{34}$ Where the order of the items does not coincide with the order of the information provided for in the schedules and building blocks according to which the prospectus is drawn up, the competent authority of the home Member State may ask the

${ }^{31}$ See Commission Regulation (EC) No 809/2004 of 29 April 2004 implementing Directive 2003/71/EC of the European Parliament and of the Council as regards information contained in prospectuses as well as the format, incorporation by reference and publication of such prospectuses and dissemination of advertisements [2004] OJ L 149/1 (Reg 809/2004/EC) art 25 para 1; András Kecskés and Vendel Halász, Stock Corporations - A Guide to Initial Public Offerings, Corporate Governance, and Hostile Takeovers (Anna Tolnai and others trs, HVG-ORAC-LexisNexis 2013) 86.

${ }^{32}$ See András Kecskés and Vendel Halász, Stock Corporations - A Guide to Initial Public Offerings, Corporate Governance, and Hostile Takeovers (Anna Tolnai and others trs, HVG-ORACLexisNexis 2013) 86-87.

${ }^{33}$ Reg 809/2004/EC art 25 para 2.

${ }^{34}$ Reg 809/2004/EC art 25 para 3. 
issuer, the offeror or the person asking for the admission to trading on a regulated market to provide a cross reference list for the purpose of checking the prospectus before its approval. Such list shall identify the pages where each item can be found in the prospectus. ${ }^{35}$

The Regulation uses schedules, which mean a list of minimum information requirements adapted to the particular nature of the different types of issuers and/or the different securities involved. ${ }^{36}$ A prospectus shall be drawn up by using one or a combination of the schedules and building blocks set out in the Regulation. ${ }^{37}$

\section{SHARE REGISTRATION DOCUMENT IN THE PROPORTIONATE DISCLOSURE REGIME}

For the share registration document, information must be disclosed in accordance with the schedule set out in Annex XXV of the Regulation. Before 2012 SMEs and large businesses were treated the same by the Regulation, but the new provisions of Annex XXV were intended to ease the weight on such entities. By enumerating the most important parts of the share registration document, the intention is to show, that these rules did not exactly result in the desired alleviation of regulatory burden.

The share registration document must indicate all persons responsible for the information given in the registration document and, as the case may be, for certain parts of it, (with, in the latter case, an indication of such parts). ${ }^{38} \mathrm{~A}$ declaration must also be attached by those responsible for the registration document that, having taken all reasonable care to ensure that the information contained in the registration document is, to the best of their knowledge, in accordance with the facts and contains no omission likely to affect its import. ${ }^{39}$

It is necessary to introduce the statutory auditors of the issuer. Information must be provided on the names and addresses of the issuer's auditors for the period covered by the historical financial information (together with their membership in a professional body). ${ }^{40}$ If auditors have resigned, been removed or not been re-appointed during the period covered by the historical financial information, details of material importance must be indicated. ${ }^{41}$

Thereafter the registration document includes selected (historical) financial information regarding the issuer, presented for each financial year for the period covered by the historical financial information, and any subsequent interim financial period, in the same currency as the financial information. The selected historical financial information must provide the key figures that summarise the financial condition of the issuer. ${ }^{42}$

The risk factors specific to the issuer or its industry shall be prominently disclosed. ${ }^{43}$

${ }^{35}$ Reg 809/2004/EC art 25 para 4; András Kecskés and Vendel Halász, Stock Corporations A Guide to Initial Public Offerings, Corporate Governance, and Hostile Takeovers (Anna Tolnai and others trs, HVG-ORAC-LexisNexis 2013) 86.

${ }^{36}$ Reg 809/2004/EC art 2 para 1.

37 Reg 809/2004/EC art 3.

38 Reg 809/2004/EC Annex XXV point 1.1.

39 Reg 809/2004/EC Annex XXV point 1.2.

${ }^{40}$ Reg 809/2004/EC Annex XXV point 2.1.

${ }^{41}$ Reg 809/2004/EC Annex XXV point 2.2.

42 Reg 809/2004/EC Annex XXV point 3.1.

${ }^{43}$ Reg 809/2004/EC Annex XXV point 4. 
The next part of the registration document is the information about the issuer. This part includes the history and development of the issuer, in which also the important events in the development of the issuer's business are mentioned. Also some basic information has to be divulged at this point, such as the legal and commercial name and place of registration of the issuer and its registration number; the domicile and legal form of the issuer, the legislation under which the issuer operates, its country of incorporation, and the address and telephone number of its registered office; and the date of incorporation and the length of life of the issuer (except where indefinite). ${ }^{44}$ Information about the investments of the issuer can also be read here, which provide a description, (including the amount) of the issuer's principal investments for each financial year for the period covered by the historical financial information up to the date of the registration document, ${ }^{45}$ and also about the issuer's principal investments that are in progress, or on which its management bodies have already made firm commitments. ${ }^{46}$

In connection with the business overview of the issuer, his principal activities ${ }^{47}$ and principal markets ${ }^{48}$ must be disclosed.

It is necessary to introduce the organizational structure of the issuer. Within the frame of this - if the issuer is part of a group - a brief description of the group and the issuer's position therein are needed. ${ }^{49}$ A list of the issuer's significant subsidiaries also has to be included, including name, country of incorporation or residence, proportion of ownership interest and, if different, proportion of voting power held. ${ }^{50}$

Property, plants and equipment of the issuer also have to be disclosed, that is information regarding any environmental issues that may affect the issuer's utilization of the tangible fixed assets can also be found here. ${ }^{51}$

It is necessary to provide a description of the issuer's financial condition, changes in financial condition and results of operations for each year and interim period, for which historical financial information is required, including the causes of material changes from year to year in the financial information to the extent necessary for an understanding of the issuer's business as a whole. ${ }^{52}$ Operating results are also important elements of the share registration document which consists of information regarding significant factors, including unusual or infrequent events or new developments, materially affecting the issuer's income from operations, indicating the extent to which income was so affected. Where the financial statements disclose material changes in net sales or revenues, a narrative discussion has to be provided of the reasons for such changes. Information regarding any governmental, economic, fiscal, monetary or political policies or factors that have materially affected, or could materially affect, directly or indirectly, the issuer's operations must be included. ${ }^{53}$

The capital resources of the company also have to be revealed in the registration document. These include information concerning the issuer's capital resources (both short

${ }^{44}$ Reg 809/2004/EC Annex XXV point 5.1.

${ }^{45}$ Reg 809/2004/EC Annex XXV point 5.2.

${ }^{46}$ Reg 809/2004/EC Annex XXV point 5.2.

47 Reg 809/2004/EC Annex XXV point 6.1.

${ }^{48}$ Reg 809/2004/EC Annex XXV point 6.2.

${ }^{49}$ Reg 809/2004/EC Annex XXV point 7.1.

${ }^{50}$ Reg 809/2004/EC Annex XXV point 7.2.

${ }^{51}$ Reg 809/2004/EC Annex XXV point 8.1.

52 Reg 809/2004/EC Annex XXV point 9.1.

${ }^{53}$ Reg 809/2004/EC Annex XXV point 9.2. 
and long term), an explanation of the sources and amounts thereof and a narrative description of the issuer's cash flows, information on the credit needs and funding structure of the issuer, information regarding any restrictions on the use of capital resources that have materially affected, or could materially affect, directly or indirectly, the issuer's operations..$^{54}$

Information must be included on research and development, patents and licenses. If it is substantial, a description shall be provided of the issuer's research and development policies for each financial year for the period covered by the historical financial information, including the amount spent on issuer-sponsored research and development activities. ${ }^{55}$

The registration document presents the most significant recent trends in production, sales and inventory, and costs and selling prices since the end of the last financial year to the date of the registration document. ${ }^{56}$ Information can also be found there on any known trends, uncertainties, demands, commitments or events that are reasonably likely to have a material effect on the issuer's prospects for at least the current financial year. ${ }^{57}$

If an issuer chooses to include a profit forecast or a profit estimate, the registration document must contain the information set out in the Regulation. ${ }^{58}$ According to Annex I. point 13.1. - 13.2., a statement shall be provided, setting out the principal assumptions upon which the issuer has based its forecast, or estimate. There must be a clear distinction between assumptions about factors which the members of the administrative, management or supervisory bodies can influence and assumptions about factors which are exclusively outside the influence of the members of the administrative, management or supervisory bodies. The assumptions must be readily understandable by investors, be specific and precise and not relate to the general accuracy of the estimates underlying the forecast. ${ }^{59}$ Also a report is necessary, which is prepared by independent accountants or auditors stating that in the opinion of the independent accountants or auditors the forecast or estimate has been properly compiled on the basis stated, and that the basis of accounting used for the profit forecast or estimate is consistent with the accounting policies of the issuer. ${ }^{60}$ Further requirements are defined by Annex XXV point 13.2. - 13.4.

Administrative, management, and supervisory bodies and senior management (names, business addresses, functions, principal activities performed outside the issuer, management expertise and experience) and their possible conflicts of interests also have to be mentioned. ${ }^{61}$ The registration document must provide information on remuneration and benefits $^{62}$, as well as board practices. ${ }^{63}$

Important information on employees of the company shall also be disclosed, namely, the actual and average number of employees and - if possible and material - a breakdown of employees by category of activity and geographic location. If the issuer employs a

${ }^{54}$ Reg 809/2004/EC Annex XXV point 10.

${ }_{55}$ Reg 809/2004/EC Annex XXV point 11.

${ }^{56}$ Reg 809/2004/EC Annex XXV point 12.1.

${ }^{57}$ Reg 809/2004/EC Annex XXV point 12.2.

58 Reg 809/2004/EC Annex XXV point 13.

59 Reg 809/2004/EC Annex XXV point 13.1.

${ }^{60}$ Reg 809/2004/EC Annex XXV point 13.2.

${ }^{61}$ Reg 809/2004/EC Annex XXV point 14.

${ }^{62}$ Reg 809/2004/EC Annex XXV point 15.

${ }^{63}$ Reg 809/2004/EC Annex XXV point 16. 
significant number of temporary employees, the number of temporary employees on average during the most recent financial year shall be indicated as well. ${ }^{64}$ With respect to administrative, management, supervisory bodies and senior management, information shall be provided as to their share ownership and any options over such shares in the issuer as of the most recent practicable date. ${ }^{65}$ A description is needed about any arrangements for involving the employees in the capital of the issuer. ${ }^{66}$

The major shareholders of the issuer must also be revealed. Within the frame of this, - in so far as is known to the issuer, - the name of any person other than a member of the administrative, management or supervisory body who, directly or indirectly, has an interest in the issuer's capital or voting rights which is notifiable under the issuer's national law, together with the amount of each such person's interest. If there are no such persons, an appropriate negative statement is necessary. ${ }^{67}$ To the extent known to the issuer, it must be stated whether the issuer is directly or indirectly owned or controlled and by whom. ${ }^{68}$ The registration document shall also describe the nature of such control and the measures in place to ensure that such control is not abused. ${ }^{69}$ Any possible changes in the control ${ }^{70}$ of the issuer shall also be described. ${ }^{71}$ The registration document shall include, whether the issuer's major shareholders have different voting rights. ${ }^{72}$

Details of related party transactions must be disclosed in the registration document in accordance with Regulation (EC) No 1606/2002 $2^{73} \cdot{ }^{74}$

The next part of the registration document is the financial information concerning the issuer's assets and liabilities, financial position and profits and losses. This contains historical financial information ${ }^{75}$, pro forma financial information ${ }^{76}$, auditing of historical annual financial information ${ }^{77}$, the age of the latest financial information ${ }^{78}$, interim and other financial information ${ }^{79}$, dividend policy ${ }^{80}$, legal and arbitration proceedings ${ }^{81}$, and any significant change in the issuer's financial or trading position ${ }^{82}$.

${ }^{64}$ Reg 809/2004/EC Annex XXV point 17.1.

${ }^{65}$ Reg 809/2004/EC Annex XXV point 17.2.

${ }^{66}$ Reg 809/2004/EC Annex XXV point 17.3.

${ }^{67}$ Reg 809/2004/EC Annex XXV. point 18.1.

68 Reg 809/2004/EC Annex XXV. point 18.3.

69 .Reg 809/2004/EC Annex XXV. point 18.3.

${ }^{70}$ Regarding changes of control transactions and takeovers in the European Union see: Vendel

Halász, 'Beveszik-e az amerikai méregpirulát az Európai Unióban?’ (2012) Európai jog Vol 123.

${ }^{71}$ Reg 809/2004/EC Annex XXV point 18.4.

72 Reg 809/2004/EC Annex XXV point 18.2.

${ }^{73}$ Regulation (EC) No 1606/2002 of the European Parliament and of the Council of 19 July 2002 on the application of international accounting standards [2002] OJ L 243/1.

${ }^{74}$ Reg 809/2004/EC Annex XXV point 19.

${ }^{75}$ Reg 809/2004/EC Annex XXV point 20.1.

${ }^{76}$ Reg 809/2004/EC Annex XXV point 20.2.

77 Reg 809/2004/EC Annex XXV point 20.3.

${ }^{78}$ Reg 809/2004/EC Annex XXV point 20.4.

${ }^{79}$ Reg 809/2004/EC Annex XXV point 20.5.

${ }^{80}$ Reg 809/2004/EC Annex XXV point 20.6.

${ }^{81}$ Reg 809/2004/EC Annex XXV point 20.7.

${ }^{82} \operatorname{Reg} 809 / 2004 / E C$ Annex XXV point 20.8. 
Pro forma financial information is to be presented as set out in Annex $\mathrm{II}^{83}$ of Commission Regulation (EC) No 809/2004, and must include the information indicated therein. This building block must include a description of the transaction, the businesses or entities involved and the period to which it refers, and must clearly state the following: the purpose to which it has been prepared; the fact that it has been prepared for illustrative purposes only; the fact that because of its nature, the pro forma financial information addresses a hypothetical situation and, therefore, does not represent the company's actual financial position or results. In order to present pro forma financial information, a balance sheet and profit and loss account, and accompanying explanatory notes, depending on the circumstances may be included. The sources of the pro forma financial information have to be stated and, if applicable, the financial statements of the acquired businesses or entities must be included in the prospectus. For further information about this building block See. Annex II of Commission Regulation (EC) No 809/2004. ${ }^{84}$ Pro forma financial information must be accompanied by a report prepared by independent accountants or auditors.

Also, the registration document must contain additional information on share capital, the Memorandum and the Articles of Association of the company. ${ }^{85}$

In connection with material contracts, a summary of each of them, other than contracts entered into in the ordinary course of business is needed, to which the issuer or any member of the group is a party, for the two years immediately preceding publication of the registration document. It is necessary to provide a summary of any other contract (not being a contract entered into in the ordinary course of business) entered into by any member of the group which contains any provision under which any member of the group has any obligation or entitlement which is material to the group as at the date of the registration document. $^{86}$

In addition, it is necessary to incorporate third party information and statement by experts and declarations of any interest in the registration document. Pursuant, where a statement or report attributed to a person as an expert is included in the registration document, such person's name, business address, qualifications and material interest in the issuer (if any) shall be indicated. If the report has been produced at the issuer's request, a statement shall be included to the effect that such statement or report is included, in the form and context in which it is included, with the consent of the person who has authorized the contents of that part of the registration document ${ }^{87}$ (see for example, the comfort letter issued by auditors) ${ }^{88}$ If information has been sourced from a third party, a confirmation shall be provided that this information has been accurately reproduced and that as far as the issuer is aware and is able to ascertain from information published by that third party, no facts have been omitted which would render the reproduced information inaccurate or misleading. Also the source of the information shall be identified. ${ }^{89}$

${ }^{83}$ Dorothee Fischer-Appelt 'The revised EU Prospectus Regulation: key changes to the contents of prospectuses' [2012] 4 (2) Law and Financial Markets Review 249.

${ }^{84}$ Reg 809/2004/EC Annex II.

${ }^{85}$ Reg 809/2004/EC Annex XXV point 21.

${ }^{86}$ Reg 809/2004/EC Annex XXV. point 22.

${ }^{87}$ Reg 809/2004/EC Annex XXV point 23.1.

88 Reg 809/2004/EC Annex XXV point 23.2.

89 Reg 809/2004/EC Annex XXV point 23.2. 
At the end of the registration document the documents on display ${ }^{90}$ and information on holdings can usually be found. The latter must disclose information relating to the undertakings in which the issuer holds a proportion of the capital likely to have a significant effect on the assessment of its own assets and liabilities, financial position or profits and losses. ${ }^{91}$

\section{PROSPECTUS REGULATION AS A BARRIER FOR SMES}

The previous enumeration of the relevant provisions regarding share registration documents (which are drafted after a thorough due diligence procedure) clearly shows that in spite of the 2010 reforms the intended alleviation of regulatory burden did not happen. The only difference between the ordinary rules laid out in Annex I and the simplified rules could only be found in among the provisions regarding the financial information. So for an SME there is no requirement for issuing own and consolidated financial statements ${ }^{92}$. The main issue is that usually SMEs are not in the position where they would be required to create. Still, the question need to be raised: did the reforms really lower the barrier for SMEs?

One of the topics of the survey conducted by the European Commission was centred on the so-called proportionate disclosure regime for "reduced market capitalisation". The intention was to find quantifiable data that for business entities the changes did not deliver the expected results as the regulations were still perceived as cumbersome. ${ }^{93}$

This question gets even more interesting, if we take it into account, that the revision of the Prospectus Directive is well-underway, the Commission has already published a proposal for a new Regulation superseding the current one. ${ }^{94}$ As for Regulation 809/2004/ $\mathrm{EC}$, there is another proposal for amending it, but it makes no mention of changing the content of any of the schedules. Looking at the roadmap for the Action Plan ${ }^{95}$, and one cannot find any indication of legislation aimed at amending or replacing the current Prospectus Directive. Thus another question needs to be asked: is there a need for such a detailed prospectus document in the case of SMEs? To answer the previously asked questions, it is advisable to take a look at some of the responses attached to the survey.

The European Securities and Markets Authority (ESMA) noted that the proportionate disclosure regime had been applied with varying degree of success, but mostly it failed to live up to the expectations. For reviewing the policies it was noted that the disclosure burden needs to be decreased significantly with regards to the investor protection scheme. The need for a study about the current application of SME disclosure regime was also brought up, as a basis for a possible future reform. ${ }^{96}$ The ESMA did not support having a

90 Reg 809/2004/EC Annex XXV point 24.

${ }^{91}$ Reg 809/2004/EC Annex XXV point 25.

${ }^{92}$ Cf Reg 809/2004/EC Annex I point 20.3 also See: Dorothee Fischer-Appelt, 'Amendments to the EU Prospectus Directive Regime' [2014] 15(2) Business Law International 103.

${ }^{93}$ See Commission 'Consultation Document Review of the Prospectus Directive' 13.

${ }^{94}$ See Commission 'Proposal on the prospectus to be published when securities are offered to the public or admitted to trading' $\operatorname{COM}(2015) 583$ final.

${ }^{95}$ See Commission 'Action Plan on Building a Capital Markets Union' (Communication) $\operatorname{COM}(2015)$ final 29-30.

${ }^{96}$ ESMA Review Of The Prospectus Directive: Public Consultation (2015) $<$ https://www.esma. europa.eu/system/files_force/library/2015/11/esma-2015-857_response_to_the_ec_public_ consultation_on_the_review_of_the_pd.pdf?download $=1>$ accessed 14 January $20167-\overline{8}$. 
bespoke regime for companies admitted to trading on SME growth markets, due to the fact that as it would hurt the principle of venue neutrality, a core component to the revision of the Prospectus Directive. ${ }^{97}$

The Luxembourg Bankers' Association's (ABBL) answers paint a different picture. According to them the proportionate disclosure regime met its original purpose; SMEs are using the schedules set out in Annex XXV. They also argued against any kind of reduction for the amount of information to be disclosed, fearing that would create an information bias. $^{98}$

The Swedish Government also evaluated the changes positively. According to their answer SMEs are frequently using the regime. Yet in their next answer it was claimed that the use of the new disclosure regime is rather limited. ${ }^{99}$ Similarly to the ABBL's response, the Swedish Government was not receptive to the idea of simplifying the prospectus regime for SMEs for entirely different reasons though. The fact that there is currently no SME growth market of any kind made the question too premature to ask in their opinion. ${ }^{100}$

In spite of some of the positive answers, the overwhelming majority of those who responded to questions relating to the prospectus document contents for SMEs ${ }^{101}$ said no to the success of the proportionate disclosure regime. ${ }^{102}$ For example, the Dutch government noted that the disclosure requirements are not alleviated by the provisions of Annex XXV. One of the reasons for that was that banks operating The Netherlands always required the full disclosure. As the proportionate disclosure regime is only optional, they are fully within their right to refuse disclosures made according to Annex XXV. ${ }^{103}$

\section{POSSIBLE FUTURE}

What lies ahead for SMEs wishing to enter the capital market in the EU? The Action Plan sets out the creation of a common MTF for SMEs specifically with the intention of facilitating cross-border fund raising. Such a common SME growth market could draw plenty of beneficial conclusions of the experiences of EU member states where such

${ }^{97}$ ESMA Review Of The Prospectus Directive: Public Consultation (2015) $<$ https://www.esma. europa.eu/system/files_force/library/2015/11/esma-2015-857_response_to_the_ec_public_ consultation_on_the_review_of the_pd.pdf?download $=1>$ accessed 14 January 20168.

${ }^{8}$ ABBL Response To Consultation Document On The Review Of The Prospectus Directive (2015) <http://www.abbl.lu/download/15964/abbl-brochure-capital-markets-union.pdf $>$ accessed 14 January 2016. 11-13.

${ }^{99}$ See Ministry of Finance, Finansinspektionen and Sveriges Riksbank, "The Swedish Government And The Swedish Authorities' Common Answer To The Consultation On A Review Of The Prospectus Directive" (2015) 15.

100 See Ministry of Finance, Finansinspektionen and Sveriges Riksbank, "The Swedish Government And The Swedish Authorities' Common Answer To The Consultation On A Review Of The Prospectus Directive" (2015) 16.

101 Out of the 147 respondents to the Commission's survey, approximately $58 \%$ percent have answered to the questions relating to the prospectus content. To see all the results, visit https:/ec. europa.eu/eusurvey/publication/prospectus-directive-2015?language $=\mathrm{en}$

102 Out of the 86 respondents to the question 53 of them answered no, 7 answered yes and 26 had no opinion.

103 The Netherlands Ministry of Finance, the Netherlands Financial Markets Authority and the Dutch Central Bank, „Response of the Netherlands - European Commission consultation document on the review of the Prospectus Directive" (2015) 12-13. 
markets are operating, or the Commission could also evaluate the situation in Australia, Canada, and the USA. ${ }^{104}$ A common characteristic of those three markets is that they abandoned the usual disclosure regulations and the prospectus requirement for SMEs; instead they set out a less cumbersome requirements, which lowered the barriers for entry. That does not mean there are not any kind of screening of the prospective entrants to the market, though. For example risk factors have to be disclosed. However, the usually regulation requires the specific risk factors pertaining to the business to be disclosed instead of the usual practice of bloating the prospectus documents with general information. Making the disclosure documents shorter improves readability as well.

It also must be noted that the Regulation intended to supersede the current Prospectus Directive holds new possibilities for the SME equity markets. As Regulations leave little to no room for member states to implement different rules; an anticipated change would be the complete harmonisation of prospectus rules, therefore effectively remove barriers of crossborder trading.

\section{CONCLUSION}

The current situation of SMEs wishing to enter the capital markets is less than ideal. As it was demonstrated, the 2010 reforms did not achieve the intended effect as the provisions are largely ignored. The reason is that the new schedules set out in Annex XXV are not bringing any real relief from the burdens of the prospectus regime. It has to be taken account that a regulatory framework tailored for large scale enterprises might be "too big to fit' on SMEs. Certain pieces of information, which might be essential for the large corporations are simply irrelevant for smaller enterprises. Forgoing the prospectus requirement for smaller listings and creating a market suitable for their needs would definitely unlock their potential.

Therefore, on a European level more needs to be done in order to reduce the dependency of SMEs on the banking sector in Europe. Changing the prospectus requirements is just one piece of the puzzle that is the access to public capital markets for the SMEs.

\section{LITERATURE}

Akerlof, G. A., 'The Market for "Lemons": Quality Uncertainty and the Market Mechanism' (1970) 3 The Quarterly Journal of Economics 488-500.

Bujtár, Zs., 'Gondolatok Kecskés András és Halász Vendel "Stock Corporations a Guide to Initial Public Offerings, Corporate Governance and Hostile Takeovers” című könyvéről' (2015) 11 Európai jog, 36-40.

Coke, M., 'Success in the Form of an IPO: A Brief Case Study of A123 Systems, Inc.' (2009) 4 Nanotechnology Law \& Business, 513-520.

104 To find out more about the Australian situation, refer to: Michael J Whincop, 'Due Diligence in SME Fundraising: Reform Choices, Economics and Empiricism' [1996] 19(2) UNSW Law Journal and Bruce Dwyer and Bernice Kotey, "Financing SME Growth: The Role Of The National Stock Exchange Of Australia And Business Advisors" (2015) 25 Australian Accounting Review. As for the Canadian situation see Stéphane Rousseau, 'The Future of Capital Formation for Small and Mediumsized Enterprises: Rethinking Initial Public Offering Regulation after the Restructuring of Canadian Stock Exchanges' [2000] 34(3) Revue Juridique Themis. 
Dwyer, B., Kotey, B., 'Financing SME Growth: The Role Of The National Stock Exchange Of Australia And Business Advisors' (2015) 25 Australian Accounting Review, 114-123.

Ferencz, B., 'Felelős társaságirányítási felvetések a General Motors gyújtáskapcsoló-botrány tükrében' (2015) 2 JURA 170-174.

Fischer-Appelt, D., 'Amendments to the EU Prospectus Directive Regime' (2014) 2 Business Law International 95-114.

Fischer-Appelt, D., 'The revised EU Prospectus Regulation: key changes to the contents of prospectuses' (2012) 2 Law and Financial Markets Review, 249-257.

Geddes, R., IPOs and Equity Offerings (Butterworth-Heinemann 2008).

Halász, V., 'Beveszik-e az amerikai méregpirulát az Európai Unióban?' (2012) 1 Európai jog 3-16.

Kecskés, A., Halász, V., Stock Corporations - A Guide to Initial Public Offerings, Corporate Governance, and Hostile Takeover (HVG-ORAC-LexisNexis 2013).

Kripke, H., 'A Search for a Meaningful Securities Disclosure Policy' (1975) 2 The Business Lawyer 293-317.

Kripke, H., 'The Myth of the Informed Layman' (1973) 2 The Business Lawyer, 293-317.

Mann, B. A., 'Prospectuses: Unreadable or Just Unread? - A Proposal to Reexamine Policies Against Permitting Projections' (1971) 2 The George Washington Law Review, 222-235.

Rousseau, St., 'The Future of Capital Formation for Small and Medium-sized Enterprises: Rethinking Initial Public Offering Regulation after the Restructuring of Canadian Stock Exchanges' (2000) 34 Revue Juridique Themis 661-760.

Spindler, J. C., 'IPO Liability and Entrepreneurial Response' (2007) 5 U Pa L Rev 1187-1228.

Varriale, G., 'Fixing Europe's Funding Model' (2013) 32 International Financial Law Review, 174183.

Whincop, M. J., 'Due Diligence in SME Fundraising: Reform Choices, Economics and Empiricism' (1996) 2 UNSW Law Journal, 433-440. 